\title{
Ketosis Treatment and Milk Yield in Dairy Cows Related to Milk Acetoacetate Levels
}

\author{
By E. Simensen, K. Halse, P. Gillund and B. Lutnas \\ Department of Large Animal Clinical Science, \\ Norwegian College of Veterinary Medicine, Oslo, Norway.
}

\begin{abstract}
Simensen E., K. Halse, P. Gillund and B. Lutnæs: Ketosis treatment and milk yield in dairy cows related to milk acetoacetate levels. Acta vet. scand. 1990, 31, 433-440. - Milk yield and milk acetoacetate (M-acac) were measured weekly for the first 6 weeks of lactation in 5 herds with a ketosis problem. Ketosis treatments and the corresponding ketotest score, were also recorded.

The treatment rate was highest 7-16 days after calving. Most of these early cases were associated with low ketone levels in milk, whereas the treatment rate for cows with high ketone levels was highest 17-31 days after calving. Nearly half of the treated cows were low-ketone animals. They were classified as ketosis cases in the cow health card records, although probably suffering from other post partum disturbances in many instances. About $40 \%$ of the cows with high ketone levels recovered spontaneously. Reduction in milk yield associated with peak M-acac levels was transient and moderate.

It was concluded that health card statistics overestimates the severity of the ketosis problem in Norway.
\end{abstract}

ketosis; ketone bodies; ketotest; acetoacetate; early lactation.

\section{Introduction}

For obvious reasons, farmers prefer to have cases of ketosis in cows treated at an early stage in the development of the disease. This often means treatment while clinical signs are still vague and unspecific. A variety of disturbances during the first weeks of lactation, before full appetite has been regained, may thus be treated as ketosis, and recorded as such on the health card of the cow in question. The consequence could be an overestimation of the ketosis problem in the cattle disease statistics based on field records of the number of ketosis treatments.

In previous field studies, $17.5 \%$ of ketosis cases were in fact classified as "doubtful" by Øverby et al. (1974), and $24 \%$ with low plasma ketone levels as "false ketosis" by Dale \& Halse (1979). In a Danish study, the test for ketone bodies in milk was negative in as many as $38 \%$ of recorded ketosis cases (Qvesel 1983).

In the present study, the ketotest score at the time of treatment, together with repeat milk yield and milk acetoacetate recordings, were used to estimate the severity of metabolic disturbances in 5 herds with a ketosis problem. The purpose was to study the relationship between clinical and subclinical ketosis, and to evaluate the reliability of the diagnosis "ketosis" as recorded in the health cards. The herds were located in NordØsterdalen, a district where many herds have a high incidence of ketosis (Simensen et al. 1987).

\section{Materials and methods}

Study design

The study was carried out in 5 herds in Tynset/Alvdal in Nord-Østerdalen, in October 
1984-January 1985. The main criterion for inclusion was a high incidence of recorded ketosis during the last few years. Average herd size in 1984 was 20.6 cows (range 12-37 cows), most calvings taking place in early autumn.

The herds were visited once per week for a period of 9-14 weeks, and data were collected from cows during the first 6 weeks of lactation. The material included a total of 86 cows. These cows were observed for a varying number of weeks, depending on calving date in relation to the date when data collection started and ended. Seventysix cows were observed for 4 weeks or more.

\section{Data collection}

Cows receiving ketosis treatment were identified from the health card records (Solbu 1983). These records also provided information concerning the result of the test for ketone bodies in milk at the time of treatment. The nitroprusside reaction (Ketotest ${ }^{(B)}$ ) was used, the test score being graded from $0=$ negative, to $3=$ strongly positive. According to Dale (1978) and Simensen et al. (1988), ketotest score of $0,1,2$ and 3 correspond to average levels of milk acetoacetate (M-acac) of about $0.05,0.2,0.4$ and 0.6 $\mathrm{mmol} / \mathrm{l}$.

During the weekly visits, daily milk yields were recorded. Pooled morning and afternoon milk samples were taken for determination of $\%$ milk fat, and morning milk samples were collected for the determination of milk acetoacetate (M-acac) concentration according to Blom \& Halse (1975). The samples were stored in liquid nitrogen until the analyses were performed.

The cows were grouped according to the magnitude of the $\mathrm{M}$-acac maxima recorded during the course of the observation period. $0.1 \mathrm{mmol} / \mathrm{l}$ is used as a discriminatory levels between high- and low-ketone maxima, sin- ce concentrations above $0.1 \mathrm{mmol} / \mathrm{l}$ were associated with significant decrease in milk yield (Fig. 2). From the present data, cows with practically constant $\mathrm{M}$-acac levels not exceeding $0.07 \mathrm{mmol} / \mathrm{l}$, were classified as low-ketone cows.

\section{Statistical analysis}

Statistical analyses were performed using conventional Student's test and covariance analyses, i.e. the GLM procedure from Statistical Analysis System ( $S A S$ 1985). Factors influencing milk yield and milk fat percentage were evaluated by models which accounted for the effect of herd $(1,2 \ldots 5)$, lactation number (1st, 2 nd and more), the nested factor cow/lactation number/herd, as well as week of lactation $(1,2 \ldots 6)$ and M-acac. The latter factor was grouped as shown in Fig. 2.

\section{Results}

\section{Treatment rates}

According to the health card records, the lactational incidence rate of ketosis in the participating herds during the whole indoor season in 1984/85 varied from 25 to $68 \%$. During the observation period, 36 of the 86 cows $(41.9 \%)$ included in the present material received treatment.

\section{Milk acetoacetate levels and ketosis treatments related to time after calving} The $\mathrm{M}$-acac average for the entire material increased gradually after calving, and was at its highest level in the period 17-31 days of lactation. Thereafter the level dropped markedly (Fig. 1).

The number of treatments per 5 days was at a maximum in the interval 7-11 days after calving. During this period, and the interval 12-16 days, the test score for ketone bodies in milk at treatment was 0 or 1 in as many as 14 of the 19 casas. In the period in which 
the $M$-acac average culminated (17-31 days), 12 of the 13 treatments were associated with a ketotest score of 2 or 3 (Fig. 1). For the whole material, $47.7 \%$ of the treatments had a ketotest score of 0 or 1 .
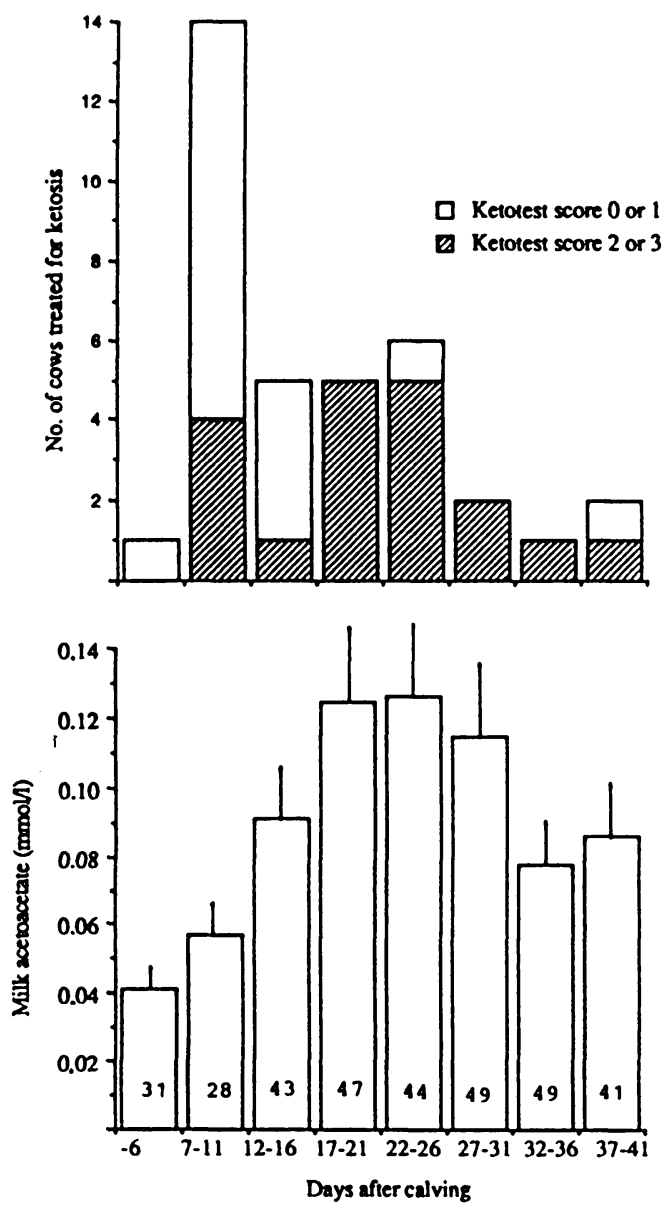

Figure 1. Milk acetoacetate levels (mean and s.e.) and number of cows treated for ketosis in different 5-day intervals after calving. Numbers at the base of the bars in the lower figure specify the number of observations in the different time intervals. In the upper figure, the cows are grouped according to ketotest score at the time of treatment (range from 0 - negative to 3 - strongly positive). Total number of cows is 86 .

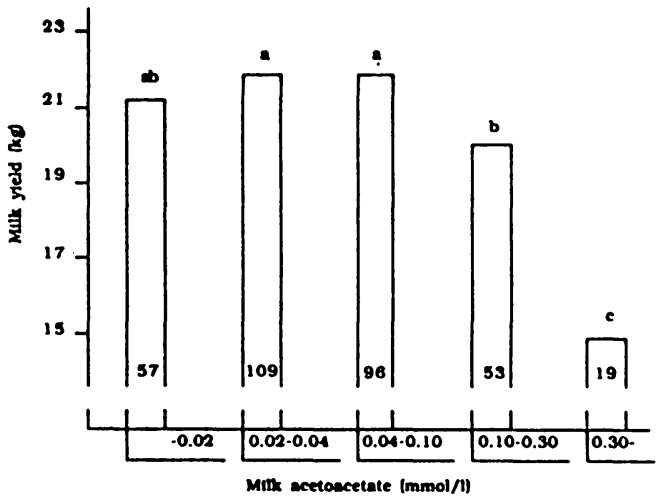

Figure 2. Milk yield (least squares means) in relation to test-day milk acetoacetate levels. Numbers at the base of the bars specify the number of observations in the different groups. Means with different letters at the top of the bars are significantly different $(p<0.005)$.

\section{Milk yield, sources of variation}

In the statistical model with milk yield as the dependent variable, all the "background" factors - herd, lactation number, week and the nested factor cow/lactation number/herd - had significant effects ( $p<$ 0.0001 ). Test-day milk yield was $19.1 \mathrm{~kg}$ in first lactation and $24.0 \mathrm{~kg}$ in later lactations. There was a significanct increase in milk yield from week 1 to week 2 , and from week 2 to week 3 . Weekly variations thereafter were not significant.

M-acac had a highly significant effect ( $p<$ 0.0001 ) on milk yield (Fig. 2). High levels (above $0.1 \mathrm{mmol} / \mathrm{l}$ ) were associated with a significant decrease in yields, while the yield appeared to be unrelated to variations in $\mathrm{M}$-acac at levels below the $0.1 \mathrm{mmol} / \mathrm{l}$ threshold.

No significant association was found between $\mathrm{M}$-acac and \% milk fat.

\section{Milk acetoacetate levels in ketosis-treated and non-treated cows}

The frequency distribution of ketosis-treated and non-treated cows according to ketone 
Table 1. Frequency distribution of ketosis-treated and non-treated cows according to milk acetoacetate maxima ${ }^{1)}$ during the observation period.

\begin{tabular}{|c|c|c|c|c|c|c|c|}
\hline \multirow[b]{3}{*}{ Cow category } & \multirow[b]{3}{*}{$\mathrm{n}$} & \multicolumn{6}{|c|}{ M-acac group 1) } \\
\hline & & \multicolumn{2}{|c|}{$>0.1 \mathrm{mmol} / 1$} & \multicolumn{2}{|c|}{$\leq 0.1 \mathrm{mmol} / \mathrm{l}$} & \multicolumn{2}{|c|}{$<0.07 \mathrm{mmol} / /$} \\
\hline & & $\mathrm{n}$ & $\%$ & $\mathrm{n}$ & $\%$ & $\mathrm{n}$ & $\%$ \\
\hline Treated & 34 & 21 & 61.8 & 13 & 38.2 & 0 & - \\
\hline Non-treated & 42 & 14 & 33.3 & 7 & 16.7 & 21 & 50 \\
\hline All & 76 & 35 & 46.1 & 20 & 26.3 & 21 & 27.6 \\
\hline
\end{tabular}

1) Based on the weekly values of $M$-acac:

$>0.1=$ Marked peak: $>0.1 \mathrm{mmol} / 1$

$\leq 0.1$ = Marked peak: $\leq 0.1 \mathrm{mmol} / \mathrm{l}$

$<0.07=$ Permantly low levels: $<0.07 \mathrm{mmol} / \mathrm{l}$

maxima during the observation period is shown in Table 1 . Of the 76 cows in the Table, 4\% had maximum $\mathrm{M}$-acac values above $0.1 \mathrm{mmol} / \mathrm{l}$. Only $28 \%$ of the cows could be classified as low-ketone cows with practically constant $\mathrm{M}$-acac levels below $0.07 \mathrm{mmol} / \mathrm{l}$ throughout the period of observation.

Table 1 further shows that in $38 \%$ of the 34 cows which were treated for ketosis, $\mathrm{M}$-acac never exceeded the $0.1 \mathrm{mmol} / 1$ limit at the weekly milk samplings. Peaks $>0.1 \mathrm{mmol} / \mathrm{l}$ were on the other hand recorded in $1 / 3$ of the cows which remained untreated.

Table 2. Results of the test for ketone bodies in milk (Ketotest) at the time of treatment for cows grouped according to maximum milk acetoacetate level during the observation period (see Table 1).

\begin{tabular}{lrrrrr}
\hline & \multicolumn{5}{c}{ Ketotest score 1) } \\
\cline { 2 - 6 } M-acac group & $\mathrm{n}$ & 0 & \multicolumn{1}{c}{1} & \multicolumn{1}{c}{2} & 3 \\
\hline 0.1 & 21 & 2 & 4 & 10 & 5 \\
$<0.1$ & 13 & 4 & 6 & 2 & 1 \\
\hline All & 34 & 6 & 10 & 12 & 6 \\
\hline
\end{tabular}

1) Range from 0 - negative to 3 - strongly positive.

\section{Ketotest and milk acetoacetate}

Table 2 shows that there was a fairly good relationship between milk ketotest score at the time of treatment and the latest M-acac value before treatment. Some divergence might be expected, as samples in most cases were obtained on different days. Actually, $63 \%$ of the cows with a low ketotest score $(0$ or 1) were in the low M-acac category. Of the 34 treated cows included in Tables 1 and $2,53 \%$ had a ketotest score of 2 or 3, whereas $62 \%$ had $\mathrm{M}$-acac maxima above $0.1 \mathrm{mmol} / \mathrm{l}$.

\section{Milk yield related to maximum milk acetoacetate levels}

In Fig. 3, data for M-acac, milk yield, and \% milk fat are shown for 4 consecutive weeks for treated and untreated cows with $\mathrm{M}$-acac maxima $>0.1 \mathrm{mmol} / \mathrm{l}$. Week 0 in the Figure represents observations in the week when peak M-acac was found. These observations are compared to the values 1 and 2 weeks before, and 1 week after the week with the maximum level. As "control" are data shown for cows with permanently low $\mathrm{M}$-acac $(<0.07 \mathrm{mmol} / \mathrm{l})$ in corresponding time periods after calving. As milk yield was 

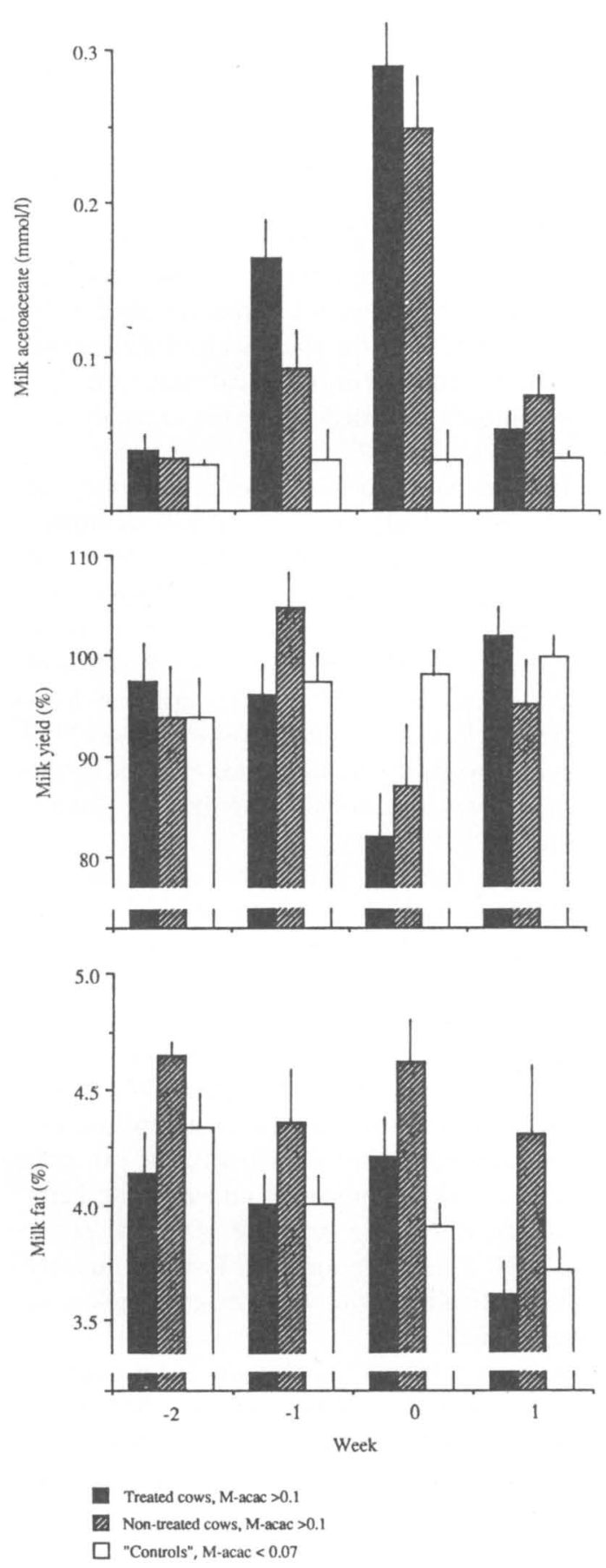

significantly lower among cows in first lactation, the data are transformed to relative values. The yield among low-ketone ("control") cows in Week 1 was set at $100 \%$.

There was a decrease in milk yield associated with ketone maxima of $3.6 \mathrm{~kg}$ in cows which received treatment, and $2.8 \mathrm{~kg}$ in untreated cows. For treated cows this decrease from Week -1 to Week 0 was significant $(p$ $<0.01$ ). The difference in yield between the high-ketone treated and control cows in Week 0 was also significant $(\mathrm{p}<0.01)$.

Fig. 3 also shows that recovery of milk yield coincided with the return to low M-acac levels. The figure does not reveal any significant association between the M-acac-related milk depression and detectable changes in milk fat concentration.

Ketosis-treated cows with detectable $\mathrm{M}$-acac maxima not exceeding $0.1 \mathrm{mmol} / \mathrm{l}$, showed no depression in milk yield during the peak period (not shown).

\section{Discussion}

The gradual increase in M-acac observed after calving, which peaked during the third to fourth week of lactation, and the subsequent marked decline after about 30 days (Fig. 1), is in agreement with other studies on ketone level fluctuations in cows (Halse \& Mogstad 1975, Dohoo \& Martin 1984, Andersson \& Emanuelson 1985). A corresponding time relationship after calving has also been reported for the occurrence of

Figure 3. Milk acetoacetate level (M-acac), milk yield, and milk fat percentage (mean and s.e.) in different weeks of lactation related to the week when peak M-acac was observed (Week 0). Data are shown for treated cows $(n=21)$ and untreated cows $(\mathrm{n}=12)$ with $\mathrm{M}$-acac maximum $>0.1$ $\mathrm{mmol} / \mathrm{l}$. Data are also shown for "control" cows $(\mathrm{n}=21)$ with permanently low M-acac levels $(<0.07 \mathrm{mmol} / \mathrm{l})$, for 4 corresponding weeks of lactation. 
ketosis (Øverby et al. 1974, Halse \& Mogstad 1975, Dohoo et al. 1983, Qvesel 1983, Gröhn et al. 1984).

In contrast to the above results, the treatment rate in the present study was at maximum as early as 7-11 days after calving, while M-acac was still low. Furthermore, the majority of these cases was associated with a low or negative ketotest score. The high-score cows in the present study actually followed the same time pattern as reported for clinical ketosis in the literature.

Based on the correspondance between ketotest score and $\mathrm{M}$-acac in Table 2 , there is reason to doubt whether the low-score casas ( 0 or 1$)$ were in fact cases of ketosis. Fig. 1 and Table 1 show that 47 and $38 \%$ of the cows which were treated for ketosis belonged to this category. This is a higher frequency than that for "doubtful" or "false" cases reported from other studies (see Introduction). If only cases with a ketotest score of 2 or 3 had been included, the incidence of seemingly genuine ketosis in this study would have been $22 \%$ instead of the $42 \%$ which was actually recorded.

From the above discussion it appears that the health card statistics which was used as basis for this study, overestimates ketosis as a disease problem. One reason for this is the difficulty in differentiating between early stages of ketosis and other conditions with similar clinical signs. Poor appetite, which is the main reason why ketosis treatment is requested, is often related to indigestions following change in feeding after calving with increasing amounts of concentrates. Indigestions are often seen in the period 7-16 days in Fig. 1 where recorded treatments were associated with a low or negative ketotest score.

Hypocalcemia can also be a possible cause of inappetence. Hove (1986) reported cycling in plasma calcium in healthy cows after calving, with nadir at about 10 days. Abomasal displacement should also be considered, although this condition is not so often diagnosed in the area.

Cows with "doubtful" ketosis which in fact is indigestion or another disease condition, are nevertheless often treated in the same manner as ketotic cows. It is a practical experience that cows often recover after such treatment. With the classification used in the health card system, the treatments are also commonly recorded under the category ketosis.

In a previous Norwegian study (Riemann et al. 1985), high rates of ketosis treatment were associated with a high standard of management and care. This could have been a reflection of the skill of the farmers in recognizing variations in the health status of the cows, and their desire to have the cows treated in an early stage of the disease. This may also be a possible factor explaining the high rate of ketosis found in the present study.

Table 1 and Fig. 3 show that about $40 \%$ of the cows in the high-ketone group recovered without treatment. It is likely that some of the cows were treated also would have recovered spontaneously if they had been left untreated. Though the effect of giving antiketogenic medicine (glucocorticoids) to cows with low ketone levels is not known, it has been assumed that such treatment can prevent the development of underfeeding ketosis by improving appetite (Dale \& Halse 1979). These relationships further illustrate the difficulties involved in diagnosing ketosis in the field.

It is well known that ketosis has a negative effect on milk yield (see amomg others Pehrson 1966, Lucey et al. 1986, Andersson 1988). In the present study, depression of milk yield appeared to be transient and moderate, $3-4 \mathrm{~kg}$ day. Some studies have 
also reported a positive association between ketone levels and milk yield (see Andersson 1988).

Logically, high yields can cause hyperketonemia due to extensive loss of carbohydrates via the milk, while low yields can be expected in ketonemia with inappetence. In the present study, ketosis-treated cows with high $\mathrm{M}$-acac levels did not show high yields before the ketone maximum (Fig. 3). The inverse relationship between $\mathrm{M}$-acac yield in the Figure thus indicates that the disease is associated with appetite disturbances. The same conclusion was drawn in a previous study involving 22 herds in Nord-Østerdalen (Simensen et al. 1988).

In conclusion, this study showed that it is difficult to clearly differentiate between ketosis and other conditions with similar clinical signs. Furthermore, it appears that health card statistics, which have been used in several epidemiological studies, overestimates ketosis as a disease problem in Norway.

\section{References}

Andersson L: Subclinical ketosis in dairy cows. Vet. Clin. N. Amer. Food Anim. Pract. 1988, 4, 233-251.

Andersson L, Emanuelson U: An epidemiological study of hyperketonaemia in Swedish dairy cows; determinants and the relation to fertility. Prev. vet. Med. 1985, 3, 449-462.

Blom AK, Halse $K$ : Corticosteroids in nocturnal blood plasma of cows in the field related to stage of lactation and plasma acetoacetate. Acta endocr. 1975, 78, 306-315.

Dale H: Feltgranskningar over ketose hjå mjølkekyr. (Field studies of ketosis in dairy cows). Thesis, Norges veterinærhøgskole. Oslo 1978.

Dale $H$, Halse $K$ : Ketose hos mjølkekyr. (Ketosis in dairy cows). Norges landbruksvitenskapelige forskningsråd. Sluttrapport 315. Oslo 1979. $47 \mathrm{pp}$.
Dohoo IR, Martin SW, Meek AH, Sandals WCD: Disease, production and culling in HolsteinFriesian cows. I. The data. Prev. vet. Med. 1983, 1, 321-334.

Dohoo IR, Martin SW: Subclinical ketosis: Prevalence and associations with production and disease. Canad. J. comp. Med. 1984, 48, 1-5.

Gröhn Y, Thompson JR, Bruss ML: Epidemiology and genetic basis of ketosis in Finnish Ayrshire cattle. Prev. vet. Med. 1984, 3, 65-77.

Halse $K$, Mogstad $O$ : Klinisk og subklinisk ketose hos kyr. - Tid etter kalving. (Clinical and subclinical ketosis in dairy cows. - Time after calving). Norsk Vet.-T. 1975, 87, 311-319.

Hove $K$ : Cyclic changes in plasma calcium and the calcium homeostatic endocrine system of the postparturient dairy cow. J. Dairy Sci. 1986, 69, 2072-2082.

Lucey S, Rowlands GJ, Russell AM: Short-term associations between disease and milk yield of dairy cows. J. Dairy Res. 1986, 53, 7-15.

Pehrson B: Studies on ketosis in dairy cows. Acta vet. scand. 1966, Suppl. 15, 7-59.

Qvesel J: Epidemiologisk undersøgelse over bovin ketose $\mathrm{i}$ en vestjysk kvægpraksis. (Epidemiological study of bovine ketosis in cattle practice). Dansk Vet.-T. 1983, 66, 378-386.

Riemann HP, Bjerke Larssen R, Simensen E: Ketosis in Norwegian dairy herds - some epidemiological associations. Acta vet. scand. 1985, 26, 482-492.

SAS (Statistical Analysis System): SAS User's Guide: Statistics. SAS Institute Inc., Cary, N.C. 1985.

Simensen E, Liestol $K$, Svela E: Ketose hos mjølkekyr i Hedmark fylke - epidemiologiske forhold. (Ketosis in dairy cows in Hedmark county, epidemiological relationships). Norsk Vet.-T. 1987, 99, 103-111.

Simensen E, Gillund $P$, Lutnas B, Alstad $O$, Halse $K$ : Factors related to dairy herds with high and low incidence of ketosis. Acta vet. scand. 1988, 29, 377-383.

Solbu $H$ : Disease recording in Norwegian dairy cattle. I. Disease incidences and non-genetic effects on mastitis, ketosis and milk fever. $Z$. Tierzücht. Züchtungsbiol. 1983, 100, 139-157. 
Overby I, Aas Hansen M, Jonsgård K, Sognen E: Bovine ketosis. I. Occurrence and incidence in herds affected by ketosis in eastern Norway 1967-1968. Nord. Vet.-Med. 1974, 26, 353361.

\section{Sammendrag}

Ketosebehandlinger og mjolkeytelse hos storfe $i$ relasjon til nivået av acetoacetat i mjolk.

Mjølkeytelse og mjølkas innhold av acetoacetat ble målt ukentlig de første ukene av laktasjonen $\mathrm{i}$ 5 besetninger med ketoseproblemer. Ketosebehandlinger og resultatet av ketotesten på mjølk ved behandling ble også registrert.

Behandlingsraten var høyest 7-16 dager etter kal- ving. Ved mange av disse tilfellene var innholdet av ketonlegmer i mjølka lavt. Behandlingsraten for kyr med høye ketonnivåer var høyest 17-31 dager ettter kalving. For hele materialet var nesten halvparten av de behandlede kyrne i lav-ketongruppen. De ble registrert som ketosetilfeller $\mathrm{i}$ helsekortene, mens mange av disse tilfellene sannsynligvis var knyttet til andre sjukdomstilstander. Ca. $40 \%$ av kyrne med høye ketonnivåer restituerte spontant. Mjølketapet $\mathrm{i}$ forbindelse med de høye acetoacetatnivåene var forbigående og moderat.

Det konkluderes med at helsekortstatistikken overestimerer ketose som et sjukdomsproblem i Norge.

\section{(Received May 16, 1989; accepted January 17, 1990).}

Reprints may be requested from: Egil Simensen, Norwegian College of Veterinary Medicine, P. O. Box 8146 Dep., N-0033 Oslo 1, Norway. 